УДК 621.373:681.325.36:621.391.7

\title{
ЦИФРОВАЯ ГЕНЕРАЦИЯ ШИРОКОПОЛОСНОГО ХАОТИЧЕСКОГО СИГНАЛА С ГРЕБЕНЧАТЫМ СПЕКТРОМ ДЛЯ СИСТЕМЫ СВЯЗИ НА ОСНОВЕ СПЕКТРАЛЬНОЙ МАНИПУЛЯЦИИ
}

\author{
ЛУКИН К. А., ЗЕМЛЯНЫЙ О. В. \\ Институт радиофизики и электроники им. А. Я. Усикова Национальной Академии наук Украинь,, \\ Украина, Харьков, 61085, ул. Проскуры 12
}

\begin{abstract}
Аннотация. Разработан алгоритм цифровой генерации широкополосного хаотического сигнала с гребенчатым спектром на основе нелинейной дискретной системы с запаздыванием. Экспериментально реализован способ передачи информации с использованием метода спектральной манипуляции с цифровой генерацией и обработкой. Результаты работы могут применяться в системах защиты передаваемой информации от несанкционированного доступа.
\end{abstract}

Ключевые слова: цифровая генерация хаотических сигналов; динамическая система с запаздывающей обратной связью; генератор сигналов произвольной формы; спектральная манипуляция хаотического сигнала

Применение шумоподобных сигналов в современных широкополосных телекоммуникационных системах позволяет обеспечить высокую помехозащищенность и устойчивое функционирование в условиях многолучевого распространения при одновременной работе многих абонентов в общей полосе частот, а также обеспечивает электромагнитную совместимость с узкополосными радиосистемами [1].

Развитие теории динамического хаоса в нелинейных системах [2] обусловило появление нового класса шумоподобных сигналов широкополосных хаотических сигналов [3], которые с успехом используются в шумовых телекоммуникационных и радиолокационных системах [4-8].

Одним из методов генерации таких сигналов является хаотизация автоколебательных систем с запаздыванием $[9,10]$, особое место среди которых занимают кольцевые автоколе- бательные системы в режимах динамического хаоса $[11,12]$, обеспечивающие большое разнообразие хаотических режимов и позволяющие получать сигналы с заданными свойствами.

В настоящее время в связи с развитием цифровых методов формирования и обработки сигналов появилась возможность создания источников хаотических сигналов на основе серийно выпускаемых цифровых устройств различной степени интеграции для телекоммуникационных, радиолокационных и навигационных систем [13-17].

Устройства, реализующие цифровую генерацию сигналов, имеют существенные преимущества по сравнению с устройствами аналогового формирования сигналов. Характеристики цифровых устройств не изменяются при изменении внешних условий, т.к. они реализуются на базе цифровых элементов, устойчиво работающих при изменении температуры, 


\section{БИБЛИОГРАФИЧЕСКИЙ СПИСОК}

1. Варакин Л. Е. Системы связи с шумоподобными сигналами / Л. Е. Варакин. - М. : Радио и связь, 1985. - $384 \mathrm{c}$.

2. Шустер Г. Детерминированный хаос: Введение / Г. Шустер ; пер. с англ. под ред. Ф. М. Израйлева. — М. : Мир, 1988. - 240 с.

3. Кислов В. Я. Новый класс сигналов для передачи информации. Широкополосные хаотические сигналы / В. Я. Кислов, В. В. Кислов // Радиотехника и электроника. - 1997. - Т. 42, № 8. - С. 962-973.

4. Kennedy M. P. Chaotic electronics in telecommunications / M. P. Kennedy, R. Rovatti, G. Setti (eds). - Boca Raton : CRC Press, 2000. - 445 p.

5. Лукин К. А. Шумовая радарная технология / К. А. Лукин // Радиофизика и электроника. - 1999. T. 4, № 3. - С. 105-111.

6. Кислов В. Я. Применение хаотических сигналов в информационных технологиях / В. Я. Кислов, В. В. Колесов, Р. В. Беляев // Радиоэлектроника. Наноситемы. Информационные технологии. - 2009. T. 1, № 1-2. - С. 23-32. - Режим доступа : http://www.raen.info/files//RENSIT 200901 p023-032. pdf.

7. Кислов В. Я. Динамический хаос и его использование в радиоэлектронике для генерирования, приема и обработки колебаний и информации / В. Я. Кислов // Радиотехника и электроника. - 1993. - Т. 38, № 10. - С. 1783-1815.

8. Сложные хаотические дискретные сигналы в системах телекоммуникации, радиолокации и навигации / Р. В. Беляев, Г. М. Воронцов, В. Я. Кислов, В. В. Колесов, С. В. Крупенин, А. М. Попов, В. И. Рябенков // Радиотехника и электроника. - 2006. Т. 51, № 9. - С. 1116-1128. - Режим доступа : http://elibrary.ru/item.asp?id=17303724.

9. Метод разностных уравнений в резонаторной задаче с нелинейным отражателем / К. А. Лукин, Ю. Л. Майстренко, А. Н. Шарковский, В. П. Шестопалов // Докл. АН СССР. - 1989. - Т. 309, № 2. С. $327-331$.
10. Кузнеиов С. П. Сложная динамика генераторов с запаздывающей обратной связью (обзор) / С. П. Кузнецов // Радиофизика. - 1982. - Т. 25, № 12. - С. 1410-1428. - (Изв. вузов).

11. Дмитриев А. С. Генерация микроволнового динамического хаоса в кольцевой автоколебательной системе на комплементарной металл-окисел-полупроводниковой структуре / А. С. Дмитриев, Е. В. Ефремова, А. Ю. Никишов // Письма в ЖТФ. - 2010. Т. 36, № 9. - С. 82-89. - Режим доступа : http://journals.ioffe.ru/articles/12391.

12. Кальянов Э. В. Кольцевая многокаскадная автоколебательная система с хаотической динамикой / Э. В. Кальянов, В. Я. Кислов, Б. Е. Кяргинский // Радиотехника. - 2005. - № 3. - С. 41-45.

13. Kolesov $V . V$. Information technologies on dynamic chaos for telecommunication, radar and navigation systems / V. V. Kolesov, A. A. Potapov // Electromagnetic Phenomena. - 2005. - Vol. 5, No. 2. P. 91-104. URL

http://www.emph.com.ua/15/kolesov.htm.

14. Lukin K. A. Millimeter-wave band noise radar/ K. A. Lukin // Telecom. Radio Eng. — 2009. — Vol. 68, No. 14. - P. 1229-1255. - DOI : 10.1615/TelecomRadEng.v68.i14.20.

15. Земляный О. В. Генераторы случайных сигналов на основе ПЛИС для шумовых радиолокаторов / О. В. Земляный, К. А. Лукин // Прикладная радиоэлектроника. - 2013. - Т. 12, № 1. - С. 32-36.

16. Программно определяемый шумовой радар на основе ПЛИС / K. A. Lukin, J. R. Moreira, P. L. Vyplavin, S. K. Lukin, and O. V. Zemlyaniy // Прикладная радиоэлектроника. - 2013. - Т. 12, № 1. C. $89-94$.

17. Цифровая система скрытой передачи информации на основе системы с запаздывавнием / А. С. Караваев, В. И. Пономаренко, Е. П. Селезнев, Е. Е. Глуховская, М. Д. Прохоров // Письма в ЖТФ. - 2011. Т. 37, № 14. - С. 24-31. - Режим доступа : http://journals.ioffe.ru/articles/14252. 
18. Дьяконов В. П. Генерация и генераторы сигналов / В. П. Дьяконов. - М. : ДМК Пресс, 2009. $384 \mathrm{c}$.

19. Gini F. Waveform Design and Diversity for Advanced Radar Systems / Fulvio Gini, Antonio De Mario, Lee K. Patton (eds). - IET Radar, Sonar and Navigation, 2012. - $552 \mathrm{p}$.

20. Земляный О. В. Передача информации на основе манипуляции спектра широкополосного хаотического сигнала / О.В.Земляный // Радиофизика и электроника. - 2015. - Т. 6, № 3. - С. 72-78.

21. System Generator for DSP. - Режим доступа : http://www.xilinx.com/products/design-tools/vivado/inte gration/sysgen.html. - Загл. с экрана.

22. Земляный О. В. Корреляционно-спектральные свойства хаоса в нелинейной динамической сис- теме с запаздыванием и асимметричным нелинейным отображением / О. В. Земляный, К. А. Лукин // Радиофизика и электроника. - 2002. - Т. 7, № 2. C. $406-414$.

23. Дмитриев А. С. Стохастические колебания в радиофизике и электронике / А. С. Дмитриев, В. Я. Кислов. - М. : Наука, 1989. — 280 с.

24. Ikeda K. Optical turbulence: Chaotic behavior of transmitted light from a ring cavity // K. Ikeda, H. Daido, O. Akimoto // Phys. Rev. Lett. — 1980. - Vol. 45, No. 9. — P. 709-712. — DOI : 10.1103/PhysRevLett.45.709. 25. Arbitrary waveform generator - AWG472. Режим доступа http://www.euvis.com/products/mod/awg/awg472.html. — Загл. с экрана. 